REFLEKSI HUKUM

Jurnal Ilmu Hukum
p-ISSN 2541-4984 | e-ISSN 2541-5417

Volume 4 Nomor 1, Oktober 2019, Halaman 97-114

DOI: https://doi.org/10.24246/jrh.2019.v4.i1.p97-114

Open access at: http://ejournal.uksw.edu/refleksihukum

Penerbit: Fakultas Hukum Universitas Kristen Satya Wacana

\title{
KAJIAN KRITIS TERHADAP PUTUSAN MAHKAMAH KONSTITUSI NOMOR 013-022/PUU-IV/2006 TENTANG PEMBATALAN PASAL PENGHINAAN TERHADAP PRESIDEN
}

\author{
Adhya Satya Lambang Bangsawan \\ Kejaksaan Negeri Boyolali \\ Korespodensi: adhyasatya@yahoo.com
}

\begin{abstract}
Abstrak
Tulisan ini membahas argumentasi hukum yang digunakan oleh Makamah Konstitusi (MK) dalam Putusan MK Nomor 013-022/PUU-IV/2006. Putusan tersebut menguji konstitusionalitas Pasal 134, Pasal 136 bis, dan Pasal 137 KUHP dimana terdapat larangan penghinaan terhadap presiden/wakil presiden yang kemudian dibatalkan oleh MK dengan konklusi pasal penghinaan terhadap presiden bukan merupakan suatu perbuatan tindak pidana. Tulisan ini bermaksud untuk menyatakan bahwa pembatalan pasal penghinaan terhadap presiden/wakil presiden tersebut, secara langsung maupun tidak langsung akan memberikan dampak yuridis bagi perlindungan terhadap martabat presiden/wakil presiden itu sendiri. Kebebasan berpendapat merupakan hak berekspresi yang sifatnya terbatas, oleh sebab itu tulisan ini juga memberikan argumentasi bahwa larangan penghinaan presiden/wakil presiden merupakan pembatasan yang konstitusional terhadap kebebasan berpendapat. Tulisan ini hendak menekankan pula bahwa status presiden/wakil presiden tidak dapat disamakan dengan rakyat biasa karena statusnya sebagai kepala negara sekaligus simbol negara.
\end{abstract}

Kata Kunci: Kebijakan; Tindak Pidana Penghinaan terhadap Presiden; Perlindungan Martabat Presiden.

\begin{abstract}
This article discusses the legal reasoning used by the Indonesian Constitutional Court in its Decision No. 013-022/PUU-IV/2006. The object of the constitutionality review is Article 134, 136 bis, and 137 of the Indonesian Criminal Code which contained the ban of insult action toward the president/vice president. Those norms have been declared null and void based on the argument that those norms were not criminal acts. Hence, this article stresses that the annulment of those norms may give negative legal consequences toward the protection of president/vice president's dignity. Freedom of speech is categorized as a right of expression which its performance is undertaken restrictively. This article argues that the ban of insult action toward the president/vice president is a constitutional limitation to the freedom of speech. The status of president/vice president shall not be considered as equal with ordinary people since president/vice president is the head of state and also the symbol of the state.
\end{abstract}

Keywords: Policy; Insult Criminal Act Toward President; Protection of President's Dignity. 


\section{PENDAHULUAN}

Tulisan ini bermaksud memberikan anotasi terhadap Putusan Mahkamah Konstitusi Nomor 013022/PUU-IV/2006 yang menguji konstitusionalitas Pasal 134, Pasal 136 bis, dan Pasal 137 KUHP. Mahkamah Konstitusi (MK) berpendapat bahwa ketentuan a quo inkonstitusional sehingga hal itu berdampak dekriminalisasi ketentuan tindak pidana penghinaan terhadap presiden atau wakil presiden dalam Kitab Undang-Undang Hukum Pidana (KUHP). Sebagai implikasinya, tindak pidana penghinaan terhadap presiden atau wakil presiden bukan lagi delik biasa, melainkan menjadi delik aduan, dengan tidak berlakunya lagi Pasal 134, Pasal 136 bis, dan Pasal 137 KUHP.

Poin utama pertimbangan hukum Putusan MK No. 013-022/PUU-IV/ 2006 adalah:

1. Pasal 134, Pasal 136 bis, dan Pasal 137 KUHP dianggap bertentangan dengan Pasal 28F Undang-Undang Dasar Negara Republik Indonesia Tahun 1995 (UUD 1945) karena berpeluang membungkam rakyat secara paksa dalam rangka menyampaikan pikiran dan pendapat kepada pemerintah yang merupakan hak asasi setiap warga negara yang dijamin oleh konstitusi tatkala ketiga pasal pidana dimaksud selalu digunakan aparat hukum terhadap momentummomentum unjuk rasa di lapangan.

2. Pasal 134 KUHP, Pasal 136 bis KUHP dianggap sudah tidak lagi relevan untuk diberlakukan karena KUHP sendiri merupakan produk perundang-undangan peninggalan Belanda yang telah berusia lebih dari 90 tahun yang kini dalam masa reformasi telah kehilangan raison d'etre-nya.

3. Pasal 134 KUHP, Pasal 136 bis KUHP ditinjau dari Pasal 1 ayat (2) UUD 1945. Redaksi pasal ini ingin menunjukkan adanya kedudukan rakyat yang lebih tinggi dari pada presiden, kedaulatan adalah di tangan rakyat. Melalui redaksi pasal ini, perlindungan secara khusus terhadap presiden dan wakil presiden tidak diperlukan.

Pasal 28F UUD 1945 memang memberikan hak kepada warga negara Indonesia untuk bebas dalam menyatakan pendapat, namun harus dibedakan antara pelaksanaan hak untuk menyatakan pendapat dengan lisan atau tulisan yang dapat berupa kritikan kepada pemerintah dan tindakan menghasut. Menyampaikan kritik kepada pemerintah secara lisan ataupun tulisan atau bahkan unjuk rasa tidak dilarang menurut ketentuan pasal a quo karena merupakan bagian dari hak setiap warga negara dan karenanya mendapat perlindungan hukum. Penyampaian pendapat di muka umum wajib menghormati hak-hak dan kebebasan orang lain, wajib tunduk kepada peraturan perundang-undangan yang berlaku, serta wajib menghormati, menjaga keamanan dan ketertiban umum. Hal ini sejalan dengan pengaturan dalam Pasal 28J ayat (1) dan (2) UUD 1945 dimana setiap orang wajib menghormati hak asasi orang lain dan adanya pembatasan hak dan kebebasan dari setiap orang.

MK, dalam pertimbangan hukumnya, nampak memberikan bobot sangat besar pada kepentingan perlindungan hak asasi manusia (HAM) dalam hal ini kebebasan 
berpendapat ketimbang kepentingan perlindungan terhadap martabat presiden atau wakil presiden. Pendekatan demikian tidak sejalan dengan pemikiran penulis. Seyogyanya pembatalan pasal penghinaan terhadap presiden perlu juga mempertimbangkan posisi presiden. Seorang presiden dalam UUD 1945, adalah kepala negara sekaligus kepala pemerintahan. Kondisi ini menunjukkan bahwa seorang presiden itu merupakan simbol dari kedaulatan, kelangsungan dan keagungan/kebesaran (the symbol of sovereignty, continuity and grandeur) dari seorang kepala negara sekaligus sebagai kepala pemerintahan. Atas dasar itu, isu hukum dari tulisan ini adalah: Apakah pertimbangan hukum Putusan MK No. 013-022/PUU-IV/ 2006 telah tepat dalam mempertimbangkan prinsip kebebasan berpendapat sebagai HAM dikaitkan dengan perlindungan terhadap martabat presiden/wakil presiden?

Terhadap isu hukum di atas penulis mengajukan tesis yang posisinya kontra terhadap pertimbangan hukum MK. Menurut penulis, keberadaan ketentuan tindak pidana penghinaan terhadap presiden atau wakil presiden sebagai delik biasa masih tetap relevan karena kebebasan berpendapat bukan hak yang absolut. MK telah gagal dalam mempertimbangkan secara tepat kaidah dari hak atas kebebasan berpendapat sehingga interpretasi MK, yang dikaitkan dengan paham kedaulatan rakyat, telah melahirkan pendekatan sangat liberal terhadap makna hak atas kebebasan berpendapat. Dua poin kekeliruan dari pertimbangan hukum MK adalah: (1) MK mengabaikan bahwa seharusnya martabat presiden/wakil presiden masih tetap relevan dilindungi melalui ketentuan hukum pidana seperti dalam KUHP, sehingga tidak ada alasan, karena asas kedaulatan rakyat, lalu presiden/ wakil presiden mendapat perlakuan sama seperti warga biasa dimana jika mengalami penghinaan maka upaya hukumnya adalah yang bersangkutan harus membuat pengaduan karena delik pidana yang berlaku adalah delik aduan; (2) MK gagal membedakan secara spesifik pendapat yang harus dilindungi oleh hukum dengan pendapat yang sebaliknya dari hak atas kebebasan berpendapat sebagai HAM.

\section{PEMBAHASAN}

\section{Perlindungan Martabat Presiden/ Wakil Presiden dan Kebebasan Berpendapat}

Poin hukum yang hendak dikemukakan disini adalah, walaupun Indonesia menganut asas kedaulatan rakyat, martabat presiden atau wakil presiden tetap relevan untuk dilindungi melalui ketentuan pidana tentang penghinaan terhadap presiden atau wakil presiden sebagai delik biasa, bukan delik aduan. Dalam kaitan dengan kebebasan berpendapat sebagai HAM, kebebasan berpendapat tersebut tidak absolut karena dalam kebebasan berpendapat tersebut ada pendapat yang memang seyogianya dilindungi dan ada juga pendapat yang tidak dilindungi. Dalam kaitan dengan perlindungan terhadap martabat presiden atau wakil presiden, kebebasan berpendapat tersebut memperoleh pembatasan. Pembatasan di sini adalah kebebasan berpendapat tidak boleh mengambil bentuk pendapat yang menghina presiden atau wakil presiden. 
Poin pertama, pengaturan domestik mengenai kebebasan berpendapat bersifat partikularistik dimana negara dapat mengimplementasikan pengaturan dengan cara yang berbeda antara satu negara dengan negara yang lain. ${ }^{1}$ Oleh karenanya, poin lanjutan yang hendak ditegaskan pada ulasan berikut adalah posisi moderat yang diambil Indonesia dalam mengatur kebebasan berpendapat tetap sejalan dengan hukum HAM internasional, sebagaimana juga sesuai dengan instrumen hukum internasional.

Dilihat dari sisi internal, UUD 1945 (sebelum amandemen) hanya mengatur secara terbatas dalam Pasal 28 yang berbunyi "Kemerdekaan berserikat dan berkumpul, mengeluarkan pikiran dengan lisan dan tulisan dan sebagainya ditetapkan dengan undang-undang". Menurut Harun Alrasid, sebagaimana dikutip Jimly Asshidiqie, bahwa UUD 1945 itu sama sekali tidak memberikan jaminan apa pun mengenai HAM. Jika diamati secara seksama, Pasal 28 itu sama sekali tidak memberikan jaminan konstitusional hak dan kebebasan berserikat (freedom of association), berkumpul (freedom of assembly), dan menyatakan pendapat (freedom of expression). Pasal 28 itu hanya menyatakan bahwa hak-hak tersebut akan ditetapkan dengan undangundang (UU). Artinya, sebelum ditetapkan dengan UU, hak itu sendiri belum ada. ${ }^{2}$
Dalam konteks instrumen hukum internasional, kebebasan berekspresi diatur dalam Universal Declaration of Human Right (UDHR)/Deklarasi Universal Hak Asasi Manusia (DUHAM) dan International Convention on Civil and Political Rights (ICCPR)/Kovensi Internasional HakHak Sipil dan Politik.

Pasal 19 DUHAM $^{3}$ menyebutkan:

"Everyone has the right to freedom of opinion and expression; this right includes freedom to hold opinions without interference and to seek, receive and impart information and ideas through any media and regardless of frontiers." (Setiap orang berhak atas kebebasan berpendapat dan berekspresi; hak ini mencakup kebebasan untuk mempunyai pendapat tanpa adanya campur tangan dan untuk mencari, mendapatkan dan memberikan informasi dan gagasan melalui media apapun dan tanpa memperhatikan batasan-batasan).

Sementara itu, Pasal 19 ICCPR $^{4}$ yang telah diratifikasi oleh Indonesia melalui UU No. 12 Tahun 2005 tentang Pengesahan Internasional Convenan On Civil And Political Rights (Konvenan Internasional tentang HakHak Sipil dan Politik), menyebutkan:

1. Setiap orang berhak untuk berpendapat tanpa campur tangan.

2. Setiap orang berhak atas kebebasan untuk menyatakan pendapat; hak ini termasuk kebebasan untuk mencari, menerima dan memberikan informasi dan pemikiran apapun, terlepas dari

Sebagai contoh, Amerika Serikat lebih cenderung mengambil posisi yang sangat bebas dalam mengatur kebebasan berpendapat warga negaranya. Hal demikian tidak terjadi di Indonesia.

2 Baca lebih lanjut Jimly Asshiddiqie, Konstitusi dan Hak Asasi Manusia, bahan disampaikan pada Lecture Peringatan 10 Tahun KontraS, Jakarta, 26 Maret 2008.

3 Article 19 of UDHR, adopted and proclaimed by General Assembly Resolution 217 A (III) of 10 December 1948.

4 Article 19 of ICCPR, adopted and opened for signature, ratification and accession by General Assembly resolution 2200A (XXI) of 16 December 1966. 
pembatasan-pembatasan secara lisan, tertulis, atau dalam bentuk cetakan, karya seni atau melalui media lain sesuai dengan pilihannya.

3. Pelaksanaan hak-hak yang dicantumkan dalam ayat 2 Pasal ini menimbulkan kewajiban dan tanggung jawab khusus. Oleh karenanya dapat dikenai pembatasan tertentu, tetapi hal ini hanya dapat dilakukan sesuai dengan hukum dan sepanjang diperlukan untuk:

a. menghormati hak atau nama baik orang lain;

b. melindungi keamanan nasional atau ketertiban umum atau kesehatan atau moral umum.

Jika dikaji lebih mendalam, ketentuan Pasal 19 ICCPR membedakan antara hak mempunyai pendapat tanpa intervensi apapun (right to hold opinions without interference) [Pasal 19 ayat (1)] dan hak untuk berekspresi (the right to freedom of expression) [Pasal 19 ayat (2)]. Hak mempunyai pendapat tanpa intervensi apapun (right to hold opinions without interference) merupakan HAM yang tidak dapat dibatasi tanpa kecuali.

Melihat pada kerangka hukum HAM secara internasional di atas, maka nampak bahwa kebebasan berpendapat bukanlah kebebasan yang absolut dimana pada praktiknya, negara diberikan kewenangan untuk membatasi sepanjang pembatasan tersebut bersifat legitimate. Dengan demikian, pengaturan kebebasan berpendapat terkait larangan penghinaan terhadap presiden/wakil presiden secara konseptual sejalan dengan hukum HAM internasional sebagai bentuk limitasi hak berpendapat.

Poin hukum kedua adalah pembatasan HAM. Penekanan statement pada poin ini adalah kesesuaian penerapan limitation clause dengan prinsip-prinsip demokrasi sebagai pilar dari hak politik, khususnya hak kebebasan berpendapat.

ICCPR dalam Pasal 19 ayat (2) mengatur hak kebebasan berekspresi termasuk didalamnya hak menyampaikan pendapat dapat dibatasi menurut ketentuan Pasal 19 ayat (3), yaitu hanya dapat dilakukan dengan:

1. berdasarkan UU (provided by law);

2. penghormatan terhadap hak atau reputasi orang lain (for respect of the rights or reputations of others);

3. untuk perlindungan keamanan nasional (for the protection of national security);

4. perlindungan keamanan umum (for the protection of public order (ordre public);

5. perlindungan kesehatan umum (for the protection of public health);

6. perlindungan moral umum (for the protection of public morals).

Meski dimungkinkan dilakukan pembatasan, tetapi pembatasan terhadap kebebasan berekspresi tidak ditujukan untuk menghilangkan hak dan kebebasan itu sendiri. ${ }^{5}$ Pembatasan terhadap batasan hak berekspresi demikian dituangkan dalam Pasal 5 ayat (1) ICCPRP yang menyebutkan:

"Nothing in the present Covenant may be interpreted as implying for any State, group or person any right to engage in any activity or perform any act aimed at the destruction of any of the rights and freedoms recognized herein or at their limitation to a greater extent than is provided for in the

$5 \quad$ Syamsul Wahidin, Hukum Pers (Pustaka Pelajar 2006) 41-42. 
present Covenant."6 (Tidak ada ketentuan dari Kovenan ini yang dapat ditafsirkan sebagai memberi hak pada suatu negara, kelompok atau perorangan untuk melakukan kegiatan yang ditujukan untuk menghancurkan hak-hak dan kebebasankebebasan yang diakui dalam Kovenan ini, atau untuk membatasinya lebih daripada yang telah ditetapkan dalam Kovenan ini).

Secara universal, kebebasan berekspresi dapat dilakukan pembatasan melalui UU sepanjang diperlukan untuk menghormati hak atau nama baik orang lain, melindungi keamanan nasional, ketertiban umum, kesehatan atau moral umum dan tidak ditujukan untuk menghilangkan hak kebebasan itu sendiri. Di Indonesia, UUD 1945 selain memberi jaminan dan promosi HAM dan bahkan mewajibkan pemerintah untuk mewujudkannya, tetapi juga mengatur bagaimana pembatasan kebebasan berekspresi. Pasal 28J ayat (1) dan (2) UUD 1945 menentukan bahwa:

1. Setiap orang orang wajib menghormati HAM orang lain dalam tertib kehidupan bermasyarakat, berbangsa dan bernegara.

2. Dalam menjalankan hak dan kebebasannya, setiap orang wajib tunduk kepada pembatasan yang ditetapkan dengan UU dengan maksud semata-mata untuk menjamin pengakuan serta penghormatan atas hak dan kebebasan orang lain dan untuk memenuhi tuntutan yang adil sesuai dengan pertimbangan moral, nilainilai agama, keamanan dan ketertiban umum dalam suatu masyarakat demokratis.
Tatanan masyarakat yang demokratis, senantiasa memperhatikan kepentingan individu pada satu sisi dengan penghormatan yang layak terhadap kebebasan yang diwujudkan dalam bentuk perilaku, yang juga merupakan penghargaan tertinggi terhadap kebebasan nurani secara seimbang. Hal ini merupakan refleksi mendasar dari pelaksanaan hak asasi yang harus senantiasa ditegaskan selaras dengan prinsip-prinsip hidup manusia beradab. Prinsip keseimbangan itu dapat terwujud dengan menyerasikan hak dan kewajiban serta tanggung jawab. ${ }^{7}$

Roh dari seluruh ketentuan UUD 1945 sebagai satu kesatuan sistem adalah semangat untuk mewujudkan Indonesia sebagai negara hukum yang demokratis dan negara demokrasi yang berdasar atas hukum. Negara hukum dan demokrasi menghormati, melindungi, dan menjamin pemenuhan kebebasan atau kemerdekaan untuk menyampaikan pendapat di dalamnya termasuk kemerdekaan untuk menyampaikan kritik terhadap Presiden. Tetapi, negara hukum dan demokrasi tidak melindungi pelaku penghinaan, terhadap siapa pun hal itu ditujukan. Pelaku penghinaan tidak dapat berlindung di balik kemerdekaan menyampaikan pendapat. Konstitusi menghormati, melindungi, dan menjamin setiap orang yang bermaksud menyampaikan pendapatnya, tetapi tidak untuk pelaku penghinaan.

Meski dimungkinkan dilakukan pembatasan, tetapi perlu batasan terhadap pembatasan itu sendiri. Menurut Patra M. Zein, penundaan

$6 \quad$ Article 5 (1) ICCPR, adopted and opened for signature, ratification and accession by General Assembly Resolution 2200A (XXI) of 16 December 1966.

$7 \quad$ Syamsul Wahidin, Op.Cit.,) 67. 
atau pembatasan kebebasan menyampaikan pendapat tidak diperbolehkan dengan alasan jika: 1) digunakan sebagai instrumen politik dan ekonomi untuk menekan orang; 2) sebagai bentuk perlakuan yang diskriminatif; 3) tidak ada dasar yang rasional dan tidak obyektif. ${ }^{8}$

Poin hukum ketiga, adanya kepentingan untuk memberikan perlindungan terhadap martabat presiden/wakil presiden sehingga asas/prinsip pembedaan perlakuan, dalam hal adanya kasus penghinaan, dapat diberlakukan. Perlindungan secara khusus martabat presiden dan wakil presiden di Indonesia menjadi hal yang mutlak, mengingat dengan sistem presidensial ada empat fungsi utama presiden berdasarkan UUD 1945, yaitu ${ }^{9}$ :

a. sebagai kepala negara (head of state);

b. sebagai kepala pemerintahan (chief executive);

c. sebagai panglima tertinggi angkatan darat, angkatan laut dan angkatan udara (commander of the army, navy and air force);

d. sebagai kepala diplomat (chief diplomat);

Menurut redaksi Pasal 4, Pasal 14 dan Pasal 15 UUD 1945, presiden merupakan pemegang kekuasaan tertinggi dalam pemerintahan. Sebagai pemegang kekuasaan tertinggi dalam pemerintahan diikuti dengan tugas dan kewajiban yang amat besar, maka seorang presiden diberi berbagai macam hak, antara memberi grasi dan rehabilitasi dengan memperhatikan pertimbangan Mahkamah Agung. Selain itu presiden juga memiliki hak untuk memberikan amnesti dan abolisi dengan memperhatikan pertimbangan Dewan Perwakilan Rakyat (DPR). Sebagai pemegang kekuasaan pemerintahan tertinggi, presiden juga diberi hak sebagai panglima tertinggi atas angkatan perang negara Indonesia, baik itu atas angkatan darat, angkatan laut maupun angkatan udara. Sedangkan dalam menjalin hubungan dengan negara lain, presiden memiliki hak untuk mengangkat duta dan konsul atau menerima penempatan duta dari negara lain dengan memperhatikan pertimbangan DPR. Selain itu presiden juga memiliki hak untuk menyatakan perang dengan negara lain setelah sebelumnya memperoleh persetujuan dari DPR. Presiden juga berhak untuk membuat perdamaian dan perjanjian dengan negara lain atas persetujuan DPR.

Dalam hukum publik, presiden adalah subjek hukum yang disebut dengan jabatan. Perlu dipahami bahwa ketika menyebut presiden berarti menyebut presiden sebagai pribadi sekaligus sebagai pemangku jabatan pemerintahan. Oleh karena itu segala tindakan hukum seorang presiden tidak dipertanggungjawabkan kepada pribadi orang, melainkan dalam kedudukannya sebagai pemangku jabatan.

Dari semua fungsi dan kedudukan yang diemban seorang presiden terlihat bahwa seorang presiden itu merupakan simbol dari kedaulatan,

\footnotetext{
8 Patra M. Zein, 'Kebebasan Menyampaikan Pendapat: Perspektif Hukum Hak Asasi Manusia' (Pertemuan Ahli 'Tinjauan tentang Tindak Pidana terhadap Kebebasan Menyampaikan Pendapat dalam RUU KUHP' diselenggarakan Komisi Hukum Nasional, Jakarta, Oktober 2008).

9 Dissenting opinions H.A.S Natabaya dalam Putusan Mahkamah Konstitusi Nomor 013-022/PUUIV/2006, Mahkamah Konstitusi, 4 Desember 2006.
} 
kelangsungan dan keagungan/ kebesaran (the symbol of sovereignty, continuity and grandeur) dari seorang kepala negara sekaligus sebagai kepala pemerintahan. Konsekuensi logis dari empat fungsi di atas maka kedudukan seorang presiden yang menjadi tokoh sentral dalam suatu negara perlu mendapat perlindungan khusus.

\section{Kesalahan/ Kekeliruan Pertimba- ngan Hukum MK dalam Mendekrimi- nalisasi Tindak Pidana Penghinaan Presiden atau Wakil Presiden}

Pada tahun 2006, Eggi Sudjana mengajukan uji materiil terhadap Pasal 134, Pasal 136 bis, dan Pasal 137 KUHP ke MK. ${ }^{10}$ Pengujian merupakan proses memeriksa, mengadili, dan memutus apakah suatu UU yang diujikan bertentangan dengan UUD 1945 atau tidak. ${ }^{11}$ Atas permohonan tersebut, MK telah memutuskan dalam Putusan MK No. 013-022/ PUU-IV/2006. Dalam amar putusannya, MK menyatakan Pasal 134, Pasal 136 bis, dan Pasal 137 KUHP bertentangan dengan UUD 1945 dan tidak mempunyai kekuatan hukum mengikat. ${ }^{12}$ Pasal penghinaan terhadap presiden dan wakil presiden dianggap inkonstitusional terhadap UUD 1945 dikarenakan adanya Pasal ini dapat membatasi hak asasi warga negara untuk menyampaikan pikiran dan pendapat, khususnya dalam hal mengkritik pemerintah. Hal ini sejalan dengan pertimbangan dalam putusan MK dimana kedudukan rakyat lebih tinggi dibandingkan oleh presiden dalam era reformasi ini. Selain itu pasal penghinaan terhadap presiden dan wakil presiden yang ada di dalam KUHP merupakan produk peninggalan Belanda yang sudah lebih dari berusia lebih dari 90 tahun.

Lebih detail, argumentasi hukum MK dalam putusan MK No. 013-022/ PUU-IV/2006 dapat menimbulkan ketidakpastian hukum (rechtsonzekerheid) karena amat rentan pada tafsir apakah suatu protes, pernyataan pendapat atau pikiran merupakan kritik atau penghinaan terhadap presiden dan/atau wakil presiden. ${ }^{13}$ Pengaturan tindak pidana penghinaan terhadap presiden atau wakil presiden juga dikhawatirkan akan mengkerdilkan kebebasan berpendapat sebagai bagian dari HAM dan pengembangan nilai demokrasi-demokratisasi. ${ }^{14}$ Martabat presiden dan wakil presiden berhak dihormati secara protokoler,

10 Adib M Asfar, 'Sejarah Pasal Penghinaan Terhadap Presiden: Dihapus MK, Dikembalikan oleh DPR dalam RKUHP (Solopos, 23 September 2019) <https://www.solopos.com/sejarah-pasal-penghi naan-presiden-dihapus-mk-dikembalikan-dpr-di-rkuhp-1020357> diakses 22 Oktober 2019.

11 Galuh Candra Purnamasari, 'Kewenangan Mahkamah Konstitusi dalam Melakukan Judicial Review terhadap Undang - Undang Ratifikasi Perjanjian Internasional' (2017) 2 (1) Refleksi Hukum: Jurnal Ilmu Hukum 1, 2.

12 Dalam Putusan Mahkamah Konstitusi Nomor 013-022/PUU-IV/2006, Mahkamah Konstitusi, 4 Desember 2006 diputus oleh 9 Hakim Mahkamah Konstitusi yaitu Jimly Asshiddiqie Ketua merangkap Anggota, H.M. Laica Marzuki, H.A.S. Natabaya, Maruarar Siahaan, Abdul Mukthie Fadjar, H. Achmad Roestandi, Harjono, I Dewa Gede Palguna, dan Soedarsono. Dari ke-9 Hakim Konstitusi, terdapat empat hakim yang mempunyai pendapat berbeda (dissenting opinions), yaitu I Dewa Gede Palguna, Soedarsono, H.A.S. Natabaya, dan H. Achmad Roestandi yang berpendapat bahwa tidak terdapat cukup alasan untuk menyatakan ketentuan-ketentuan yang dimohonkan pengujian dalam permohonan a quo sebagai ketentuan-ketentuan yang bertentangan dengan UUD 1945, sehingga permohonan ini seharusnya dinyatakan ditolak.

13 Putusan Mahkamah Konstitusi Nomor 013-022/PUU-IV/2006, Mahkamah Konstitusi, 4 Desember 2006.

14 Lidya Suryani Widayati, 'Tindak Pidana Penghinaan Terhadap Presiden dan Wakil Presiden: Perlukah Diatur Kembali dalam KUHP?' (2017) 8 (2) Negara Hukum 215, 218. 
namun tidak boleh mendapatkan perlakuan privilege hukum secara diskriminatif berbeda dengan kedudukan rakyat banyak. ${ }^{15}$ Selanjutnya MK berpendapat bahwa Indonesia sebagai suatu negara hukum yang demokratis, berbentuk republik, dan berkedaulatan rakyat, serta menjunjung tinggi HAM sebagaimana telah ditentukan dalam UUD 1945, tidak relevan lagi jika dalam KUHP-nya masih memuat pasal-pasal seperti Pasal 134, Pasal 136 bis, dan Pasal 137 yang menganut prinsip persamaan di depan hukum, mengurangi kebebasan mengekspresikan pikiran dan pendapat, kebebasan akan informasi, dan prinsip kepastian hukum. RUU KUHP yang merupakan upaya pembaharuan KUHP warisan kolonial juga harus tidak lagi memuat pasal-pasal yang isinya sama atau mirip dengan Pasal 134, Pasal 136 bis, dan Pasal 137 KUHP. Terlebih lagi, ancaman pidana terhadap pelanggaran Pasal 134 paling lama enam tahun penjara dapat dipergunakan untuk menghambat proses demokrasi khususnya akses bagi jabatan-jabatan publik yang mensyaratkan seseorang tidak pernah dihukum karena melakukan tindak pidana yang diancam dengan pidana penjara lima tahun atau lebih. 16

Merespon argumentasi MK di atas, maka tulisan ini hendak menekankan pada poin utama dari anotasi yaitu cara MK memperlakukan asas kedaulatan rakyat sehingga pembedaan antara presiden/wakil presiden dengan rakyat biasa menjadi tidak relevan ketika terjadi kasus pidana yaitu penghinaan. Dalam hal ini, MK mempersamakan begitu saja, atas dasar kedaulatan rakyat, perlakuan kepada presiden/wakil presiden dengan rakyat biasa, sehingga proses hukum kasus ini adalah penghinaan menjadi isu personal, dimana penghinaan kepada presiden/wakil presiden menjadi delik aduan. Mengkaitkan dengan pembahasan yang sebelumnya bahwa hukum tentang kebebasan berpendapat tidak menjadikan kebebasan berpendapat hak absolut; pembatasan dapat dilakukan terhadap kebebasan berpendapat dalam koridor demokrasi; dan pada akhirnya perlindungan terhadap martabat presiden/ wakil presiden adalah dasar untuk pembatasan terhadap kebebasan berpendapat sehingga penghinaan kepada presiden/wakil presiden harus tetap seperti hukumnya semula sebagai delik biasa.

\section{Legal Reasoning Pertama}

Berkaitan dengan legal reasoning yang pertama, penulis tidak sependapat dengan pandangan MK yang menyatakan bahwa Pasal 134 KUHP, Pasal 136 bis KUHP dan Pasal 137 KUHP akan membungkam rakyat dalam menyampaikan pikiran dan pendapatnya kepada pemerintah.

Pada dasarnya pertimbangan MK dapat dinyatakan sebagai berikut:

"Hak atas kemerdekaan (kebebasan) menyatakan pendapat (freedom of opinion and expression) merupakan hak asasi yang sangat penting. Secara konstitusional Pasal 28 UUD 1945,

\footnotetext{
15 Putusan Mahkamah Konstitusi Nomor 013-022/PUU-IV/2006, Mahkamah Konstitusi, 4 Desember 2006.

16 Putusan Mahkamah Konstitusi Nomor 013-022/PUU-IV/2006, Mahkamah Konstitusi, 4 Desember 2006.
} 
mengakui adanya kemerdekaan berserikat dan berkumpul, mengeluarkan pikiran dengan lisan dan tulisan dan sebagainya ditetapkan dengan UU. Kebebasan HAM ini berkaitan dengan UU. Kebebasan HAM berkaitan dengan kemerdekaan ini, merupakan pintu masuk (entry point) terhadap pengakuan adanya HAM. Terkait dengan kebebasan HAM, Pasal 28 E ayat (2) UUD 1945 menyatakan setiap orang berhak atas kebebasan berkumpul dan mengeluarkan pendapat. Secara lebih ekplisit Pasal 28 F UUD 1945 menyatakan bahwa setiap orang berhak untuk berkomunikasi dan memperoleh informasi untuk mengembangkan pribadi dan lingkungan sosialnya, serta berhak mencari, memperoleh, memiliki, menyimpan, mengolah, dan menyampaikan informasi dengan menggunakan segala jenis saluran yang tersedia. Berdasarkan Pasal 28 UUD 1945 khususnya Pasal 28E ayat (2) UUD 1945 dan Pasal 28F UUD 1945, pasal mengenai penghinaan terhadap presiden atau wakil presiden dicabut. Pasal 134, Pasal 136 bis, dan Pasal 137 KUH Pidana dianggap bertentangan dengan Pasal 28F UUD 1945 karena berpeluang membungkam rakyat secara paksa dalam rangka menyampaikan pikiran dan pendapat kepada pemerintah yang merupakan hak asasi setiap warga negara yang dijamin oleh konstitusi tatkala ketiga pasal pidana dimaksud selalu digunakan aparat hukum terhadap momentum-momentum unjuk rasa di lapangan. Hal dimaksud secara konstitusional bertentangan dengan Pasal 28, Pasal 28E ayat (2), dan ayat (3) UUD 1945."

Legal reasoning pertama di atas sebagai dasar pembatalan pasal mengenai penghinaan terhadap presiden atau wakil presiden ini, menurut penulis perlu dikaji lebih dalam. Penulis berpendapat bahwa arti kebebasan itu sendiri sebenarnya bersifat anomali atau mendua. Dalam hal ini dimaksudkan sebagai istilah untuk menyatakan ketidakterikatan untuk berbuat sesuatu yang sesuai dengan kehendak dan hati nuraninya maka makna ilmiah yang dikandung oleh kebebasan secara universal. ${ }^{17}$ Kebebasan termasuk suatu yang bersifat asasi. Pada umumnya para pemikir mempunyai persepsi yang sama tentang apa saja kebebasan yang harus ada pada setiap insan. Hanya rincian selanjutnya yang seringkali menimbulkan permasalahan tentang batas-batas kebebasan yang bisa dinikmati setiap orang. Secara deskriptif, kebebasan tidak akan mungkin diartikan sebebas-bebasnya. Akan senantiasa ada pembatasan baik oleh kelemahan yang bersifat internal (psikis, moral) maupun oleh batasan yang bersifat eksternal seperti paksaan atau sebagainya ${ }^{18}$.

Di dalam konteks yang lebih seimbang, kebebasan itu harus senantiasa sejalan dengan tanggung jawab. Kebebasan dalam arti ini mengharuskan seseorang untuk melakukan tindakan dengan memperhatikan kebebasan orang lain yang juga memiliki hal yang sama. Dengan demikian pada dasarnya kebebasan itu harus dimaknai secara kontekstualitas dan ada batas tertentu khususnya dalam hidup bermasyarakat. Pemberian batas kebebasan tidak berarti mengurangi atau menghilangkan kebebasan itu sendiri namun bertujuan agar menata kehidupan dalam bermasyarakat agar masingmasing pihak dapat mengenyam 
haknya. Sebab pada hakekatnya kebebasan bukan berarti berbuat sekehendak hati melainkan untuk mengakui dan menghormati adanya hak serta kewajiban setiap manusia pada umumnya. Oleh karena itu dibutuhkan adanya satu ketegasan antara hak-hak yang bersifat individual dengan hak-hak yang bersifat sosial ${ }^{19}$.

Sampai seberapa jauh HAM tersebut dapat diseimbangkan akan bergantung pada pengaturan masing masing negara. Hal ini merupakan satu fundamental rights yang dalam bentuk formal yang dituangkan dalam Konstitusi atau UUD. Dari konstitusi atau UUD ini secara lebih operasional dituangkan dalam UU. Dengan demikian sumber dari HAM itu berasal dari karunia Tuhan. Sedangkan fundamental rights yang tertuang dalam konstitusi atau UUD dan selanjutnya dijabarkan dalam UU bukan merupakan sumber hak.

Ketentuan perihal kebebasan mengeluarkan pendapat dengan tulisan itu diatur dalam Pasal 28 UUD 1945 yang menyatakan bahwa kebebasan mengeluarkan pendapat dengan tulisan atau dengan lisan dan lain-lain diatur oleh UU. Pasal ini berusaha memberikan legalitas berbagai aktivitas, misalnya hak untuk demonstrasi atau berunjuk rasa yang merupakan refleksi dari hak untuk berbicara dalam forum-forum tertentu seperti dalam pertemuanpertemuan ilmiah, yang kesemuanya itu memerlukan pengaturan UU. Namun sudah selayaknya berbagai keinginan itu diimbangi dengan pemenuhan kewajiban warga negara secara lebih seimbang. Dalam arti juga disertai dengan tanggung jawab akan kesejahteraan bersama dengan tidak membuat kesengsaraan dan kesulitan bagi pihak lain. Pada era demokrasi yang menuntut lebih banyak keterbukaan, kritik, sumbang saran atau apapun namanya itu sangat diperlukan adanya pembatasan terhadap kebebasan yang berlebihan.

Sejatinya kritik terhadap pemerintahan bukan tanpa batas, ramburambu selalu ada dan setiap kesalahan yang dilakukan oleh seseorang juga bermuara pada proses hukum. Muncul adanya hak untuk mengeluarkan pendapat pada satu sisi dengan kewajiban untuk menghargai pemerintahan pada sisi lain untuk terus mencari keseimbangan. Oleh sebab itu upaya ini akan melahirkan prinsip mengedepankan kebebasan yang berbudi luhur sebagai suatu idealisme tanpa ada upaya menjatuhkan pemerintahan dengan tindakan yang merusak citra pemerintahan itu sendiri, antara lain melalui tindakan penghinaan. Perlu ditanamkan bahwa kebebasan bukan berarti berbuat sekehendak hati melainkan untuk mengakui dan menghormati adanya hak serta kewajiban setiap manusia.

Roh dari seluruh ketentuan UUD 1945 sebagai satu kesatuan sistem adalah semangat untuk mewujudkan Indonesia sebagai negara hukum yang demokratis dan negara demokrasi yang berdasar atas hukum. Negara hukum dan demokrasi menghormati, melindungi, dan menjamin pemenuhan kebebasan atau kemerdekaan untuk menyampaikan pendapat di dalamnya termasuk kemerdekaan untuk menyampaikan kritik terhadap presiden. Tetapi, negara hukum dan demokrasi tidak melindungi pelaku penghinaan, terhadap siapa pun hal 
itu ditujukan. Pelaku penghinaan tidak dapat berlindung di balik kemerdekaan menyampaikan pendapat. Konstitusi menghormati, melindungi, dan menjamin setiap orang yang bermaksud menyampaikan pendapatnya, tetapi tidak untuk pelaku penghinaan.

Menjadi hal yang berbeda ketika menghadapkan secara diametral bahwa pengaturan pasal-pasal mengenai penghinaan terhadap presiden atau wakil presiden dianggap sebagai upaya menghambat kebebasan untuk mengemukakan pendapat. Ketika ada hak kebebasan berpendapat, termasuk di dalamnya kebebasan untuk mengkritik presiden atau wakil presiden, maka disitu juga akan muncul batasan terhadap hak kebebasan berpendapat.

Batasan ini dapat berupa batasan yang bersifat eksternal seperti paksaan. Paksaan untuk tetap menghormati pemerintah walaupun dalam upaya mengkritisi kebijakan atau perilaku presiden atau wakil presiden. Atas dasar pemerintah harus menjaga dan membatasi pelaksaan hak untuk berpendapat dalam hal ini mengkritik presiden atau wakil presiden, maka pemerintah mengeluarkan atau mengakomodasi pasalpasal mengenai penghinaan terhadap presiden atau wakil presiden (Pasal 134, Pasal 136 bis dan Pasal 137 KUHP) sebagai landasan hukum dalam mengatur batasan kritikan terhadap pemerintah.

Menurut Oemar Seno Adji, salah satu persyaratan yang harus diperhatikan apabila dalam hukum pidana akan mengatur mengenai pembatasan terhadap kebebasan pers, dalam hal ini kebebasan untuk berpendapat termasuk di dalamnya kebebasan untuk mengkritik pemerintahan, yaitu harus ada pembatasan yang bersifat limitatif, untuk hal- hal tertentu akibat dari abuse of liberty, seperti perbuatan: 20

1. Penghinaan (baik penghinaan biasa atau ringan atau penghinaan formil dan material).

2. Hasutan.

3. Blasphemy (pernyataan yang ditujukan terhadap agama).

4. Pornografi.

5. Berita bohong.

6. Keamanan nasional dan ketertiban umum ("national security" dan "public order").

7. Pernyataan yang menghambat jalannya peradilan ("impede the fair administration of justice”).

Hal ini sejalan sebagaimana dalam Pasal 28J ayat (1) dan (2) UUD 1945 yang menyatakan bahwa HAM dapat dibatasi oleh negara melalui UU dengan maksud semata-mata untuk menjamin pengakuan, penghormatan dan pelaksanaan HAM dalam kehidupan bermasyarakat, berbangsa dan bernegara.

Benar bahwa terdapat potensi atau kemungkinan terjadinya pelanggaran terhadap hak-hak konstitusional, khususnya yang diatur dalam Pasal 28 dan Pasal 28E Ayat (2) dan (3) UUD 1945, yakni dalam hal terdapat keadaan di mana seseorang yang menyampaikan kritik terhadap presiden, oleh penyidik atau penuntut umum dinilai sebagai penghinaan terhadap presiden. Namun, andaikata pun keadaan demikian terjadi, hal itu bukanlah merupakan persoalan konstitusionalitas norma melainkan

20 Pujiyono, Kumpulan Tulisan Hukum Pidana-Kriminalisasi Atas Kebebasan Pers dalam Perspektif Hukum Pidana (CV Mandar Maju 2007) 143. 
persoalan penerapan norma. Suatu norma yang konstitusional tatkala diterapkan di dalam praktik oleh aparat penegak hukum memang terdapat kemungkinan melanggar hak-hak konstitusional seseorang, antara lain karena keliru dalam menafsirkannya. Namun, kekeliruan dalam penafsiran dan penerapan norma sama sekali berbeda dengan inkonstitusionalitas norma.

\section{Legal Reasoning Kedua}

MK menyatakan bahwa Pasal 134 KUHP, Pasal 136 bis KUHP dianggap sudah tidak lagi relevan untuk diberlakukan karena KUHP sendiri merupakan produk perundangundangan peninggalan Belanda yang telah berusia lebih dari 90 tahun. MK mendasarkan pada pandangan J.E. Sahetapy yang menyatakan bahwa perlu diingat Pasal V OendangOendang No. 1 Tahun 1946 yang merupakan toets steen (batu penguji) tentang relevansi dan raison d'etre pasal-pasal KUHP. Pasal V OendangOendang No. 1 Tahun 1946 dimaksud menyatakan:

"Peraturan hukum pidana yang seluruhnya atau sebagian sekarang tidak dapat dijalankan, atau bertentangan dengan kedudukan Republik Indonesia sebagai negara merdeka, atau tidak mempunyai arti lagi, harus dianggap seluruhnya atau sebagian sementara tidak berlaku".

Dengan demikian memandang Pasal 134, Pasal 136 bis, dan Pasal 137 KUHP dalam era demokrasi reformasi tidak lagi relevan dan hilang raison d'etre-nya. Delik penghinaan tidak boleh lagi digunakan untuk menghambat kritik dan protes terha- dap kebijakan pemerintah (pusat dan daerah), maupun pejabat pemerintah (pusat dan daerah) sehingga tidak perlu lagi ada delik penghinaan khusus terhadap presiden dan wakil presiden, dan cukup dengan adanya Pasal 310-321 KUHP. ${ }^{21}$

Penulis tidak sependapat dengan pandangan ini. Sebagaimana telah diuraikan di atas bahwa dalam suatu negara republik dengan sistem pemerintahan presidensial sebagaimana dianut oleh UUD 1945, kedudukan presiden mempunyai makna yang sangat penting karena karena martabat negara adalah melekat pada diri seorang presiden/wakil presiden. Hal ini dikarenakan menurut UUD 1945, ada empat fungsi utama presiden yaitu sebagai kepala negara (head of state), kepala pemerintahan (chief executive), panglima tertinggi angkatan darat, angkatan laut dan angkatan udara (commander of the army, navy and air force dan sebagai kepala diplomat (chief diplomat). Presiden adalah subjek hukum yang disebut dengan jabatan. Ketika menyebut seorang presiden berarti menyebut presiden sebagai pribadi sekaligus sebagai pemangku jabatan pemerintahan. Oleh karena itu segala tindakan hukum seorang presiden tidak dipertanggungjawabkan kepada pribadi orang, melainkan dalam kedudukannya sebagai pemangku jabatan.

Dari semua fungsi dan kedudukan yang diemban seorang presiden terlihat bahwa seorang presiden itu merupakan simbol dari kedaulatan, kelangsungan dan keagungan/ kebesaran (the symbol of sovereignty, continuity and grandeur) dari seorang

21 Putusan Mahkamah Konstitusi Republik Indonesia Nomor 013-022/PUU-IV/2006, Mahkamah Konstitusi, 4 Desember 2006. 
kepala negara sekaligus sebagai kepala pemerintahan. Seorang presiden yang menjadi tokoh sentral dalam suatu negara perlu mendapat perlindungan khusus. Oleh sebab itu adalah hal yang logis ketika negara Indonesia, melalui KUHP memberikan pasal-pasal yang mengatur perlindungan yang lebih khusus kepada presiden dan wakil presiden, seperti dalam Pasal 134 KUHP, Pasal 136 bis KUHP dan Pasal 137 KUHP. Tidak sepantasnya presiden yang berkedudukan sebagai kepala negara sekaligus sebagai kepala pemerintahan disejajarkan dengan masyarakat biasa dalam pengaturan jika terjadi penghinaan. Jika hal ini terjadi, penghinaan kepada presiden selaku kepala negara dan sekaligus kepala pemerintahan akan akan dapat dinyatakan sebagai delik jika dilakukan pengaduan.

Ketidak sepakatan penulis juga pada apa yang dikemukakan oleh J.E. Sahetapy yang dipakai sebagai dasar pemikiran MK. Penulis lebih sependapat penafsiran Prof. Sudarto, bahwa Pasal 5 UU No. 1 Tahun 1946 tersebut tidak dapat dipergunakan untuk menguji delik-delik yang tercantum dalam KUHP, karena perubahan pasal-pasal dalam KUHP telah diatur dalam pasal VIII UU No. 1 Tahun 1946.22 Menurut penulis, pendapat Sudarto merupakan hal yang masuk akal karena dalam Pasal VIII UU No. 1 Tahun 1946 sendiri memuat perubahan kata-kata dan penghapusan berbagai pasal dalam KUHP.

Meskipun KUHP merupakan peninggalan penjajah Belanda, dan telah berusia seratus tahun lebih, pemuatan pasal-pasal yang berkaitan dengan perlindungan terhadap presiden dan wakil presiden, tidak dapat begitu saja ditolak secara apriori, karena secara alamiah delikdelik tersebut pada hakekatnya adalah instrumen penyeimbangan dalam rangka melindungi HAM (warga negara) dari segala tindak pidana yang mungkin muncul. Esensinya bukan karena KUHP produk peninggalan penjajah, sehingga secara apriori harus ditolak, akan tetapi bertumpu pada fungsi dan tujuannya yaitu perlindungan masyarakat itu sendiri. ${ }^{23}$

\section{Legal Reasoning Ketiga}

Alasan pembatalan pasal penghinaan terhadap presiden adalah ditinjau dari Pasal 1 ayat (2) UUD 1945. Redaksi pasal ini ingin menunjukkan adanya kedudukan rakyat yang lebih tinggi dari pada presiden. Kedaulatan adalah ditangan rakyat. Melalui redaksi pasal ini, perlindungan secara khusus terhadap presiden dan wakil presiden tidak diperlukan.

Terhadap legal reasoning ketiga ini penulis juga tidak sependapat dengan pertimbangan MK. Memang pada dasarnya rakyat lebih tinggi dari pada presiden, tetapi harus diingat bahwa dalam hal ini adalah rakyat dalam konteks rakyat secara keseluruhan. Berbeda maknanya ketika melihat rakyat sebagai individu dibandingkan dengan presiden. Tentunya presiden akan memiliki kedudukan yang lebih tinggi dibandingkan rakyat sebagai seorang individu, baik itu dilihat dari

\footnotetext{
22 Yesmil Anwar dan Adang, Pembaharuan Hukum Pidana - Reformasi Hukum Pidana (Gramedia Widiasarana Indonesia 2008) 122.

23 Pujiyono, Op.Cit., 142.
} 
hak dan kewajiban yang dimilikinya. Pernyataan ini jangan dilihat sebagai kondisi dimana tidak dianutnya perlakuan yang sama secara hukum (asas equality before the law). Equality before the law harus diartikan bahwa setiap orang sama di mata hukum dalam hal yang sama. "Dalam hal yang sama" adalah upaya untuk menjaga keseimbangan yang memang telah menjadi dasar dimana hak dan kewajiban dari tiap pihak diterima dan diberlakukan sebagaimana mestinya.

Dalam kaitannya dengan perlu adanya perlindungan secara khusus terhadap pemerintah incasu perlindungan terhadap martabat presiden dan wakil presiden selaku pemerintah melalui delik penghinaan terhadap presiden dan wakil presiden maka asas persamaan dimata hukum itu harus dilihat secara lebih bijaksana. Status atau posisi presiden dan wakil presiden berbeda dengan orang biasa pada umumnya, maka tidak pada tempatnya pemuatan pasal-pasal yang berkaitan dengan perlindungan terhadap presiden dan wakil presiden dihadapkan dengan prinsip equality before the law. Persamaan di muka hukum sebagaimana diatur dalam Pasal 27 ayat (1) UUD 1945, tidaklah berarti bahwa tiap UU harus berlaku terhadap semua orang yang karena sifatnya, pencapaiannya atau keadaannya memang berbeda satu sama lain. Persamaan dimata hukum bukan berarti delik penghinaan terhadap presiden dan wakil presiden harus dihapuskan dan bagi presiden dan wakil presiden diberlakukan delik penghinaan biasa. Pengaturan pasal penghinaan terhadap presiden dan wakil presiden sebagaimana yang diatur dalam Pasal 134, 136B bis dan 137 KUHP, itu diperlukan dan diperbolehkan sepanjang terdapat alasan yang sah menurut hukum (reasonable) dan tidak sewenangwenang (arbitrary). Putusan MK dalam perkara No. 070/PUU-II/2004, yang menyatakan antara lain "keadilan adalah memperlakukan sama terhadap hal-hal yang sama dan memperlakukan berbeda terhadap hal-hal yang memang berbeda".

Perlu juga diingat perbuatan menghina pada hakekatnya merupakan perbuatan yang sangat tercela. Ketentuan yang berlaku universal, dalam tradisi hukum apa pun baik itu dilihat dari aspek moral, agama, nilainilai kemasyarakatan dan nilai HAM, bahwa penghinaan merupakan tindak pidana. Penghinaan merupakan perbuatan yang menyerang martabat kemanusiaan, oleh sebab itu secara teoritik dipandang sebagai mala per se.

Benar bahwa terdapat potensi atau kemungkinan terjadinya salah penafsiran dalam hal terdapat keadaan dimana seseorang yang menyampaikan kritik terhadap presiden, oleh penuntut umum dinilai sebagai penghinaan terhadap presiden. Namun, andaikata pun keadaan demikian terjadi, hal itu bukanlah merupakan persoalan konstitusionalitas norma melainkan persoalan penerapan norma.

Di dalam sistem KUHP sendiri juga menganut adanya sistem gradasi nilai. Hal ini tergambar dalam adanya pengelompokan perlindungan pada setiap elemen masyarakat dan perbedaan kualitas dan kuantitas hukuman, khususnya pidana penjara dari setiap subjek hukum (korban) yang ingin dilindungi. Secara singkat dapat dijelaskan sebagai berikut:

a. Adanya pengaturan secara khusus mengenai perlindungan terhadap presiden atau wakil presiden yang 
dibedakan dari perlindungan terhadap masyarakat biasa.

b. Adanya pengaturan secara khusus mengenai perlindungan terhadap raja atau kepala negara sahabat maupun wakil negara asing di Indonesia yang dibedakan dari perlindungan terhadap masyarakat biasa.

c. Adanya pengaturan secara khusus mengenai perlindungan terhadap presiden atau wakil presiden yang dibedakan dari perlindungan terhadap raja atau kepala negara sahabat maupun wakil negara asing di Indonesia.

d. Adanya pengaturan secara khusus mengenai perlindungan terhadap agama yang dibedakan dari perlindungan terhadap presiden dan wakil presiden, raja atau kepala negara sahabat maupun wakil negara asing di Indonesia dan masyarakat pada umumnya.

Ketika salah satu pasal dalam sistem ini dicabut secara parsial dan tidak konsisten, maka tentunya akan memberikan dampak yuridis yang cukup besar terhadap keutuhan sistem tersebut. Dalam kasus ini ketika pasal penghinaan terhadap presiden dicabut, secara tidak sadar pembatalan pasal ini telah merusak sistem dalam pencantuman pasalpasal yang mengatur mengenai perbuatan penghinaan secara keseluruhan. Hal ini terlihat dengan masih tercantumnya pasal penghinaan terhadap raja atau kepala negara sahabat maupun wakil negara asing di Indonesia. Tidak ikut dicabutnya pasal penghinaan terhadap raja atau kepala negara sahabat maupun wakil negara asing di Indonesia menunjukkan bahwa pembatalan pasal terhadap presiden atau wakil presiden tidak memperhatikan sistem dan pola yang digunakan dimana KUHP bersandar pada gradasi nilai terhadap pihakpihak yang berusaha untuk dilindungi. Hal memiliki konskuensi bahwa seolah-olah KUHP hanya memberikan perlindungan khusus terhadap raja atau kepala negara sahabat maupun wakil negara asing di Indonesia dari tindak pidana penghinaan sedangkan Presiden atau Wakil Presiden Indonesia tidak memperoleh perlindungan khusus selayaknya raja atau kepala negara sahabat maupun wakil negara asing di Indonesia. Menurut penulis hal ini tidak wajar, karena seharusnya KUHP diberlakukan di Indonesia digunakan sepenuhnya untuk melindungi masyarakat Indonesia secara umum. Jadi sudah seharusnya Presiden atau Wakil Presiden Indonesia memperoleh "prioritas" perlindungan dibandingkan seorang raja atau kepala negara sahabat maupun wakil negara asing di Indonesia. Ketika hanya seorang raja atau kepala negara sahabat maupun wakil negara asing di Indonesia yang hanya dilindungi oleh KUHP, tentu saja konsep ini telah melenceng jauh dari sistem dan pola gradasi nilai yang dianut oleh KUHP.

Hal yang sama juga masih diaturnya mengenai penodaan terhadap bendera dan lambang negara Republik Indonesia serta bendera negara asing, juga seolah-olah memberikan gambaran bahwa pembatalan pasal penghinaan terhadap presiden dan wakil presiden merupakan hal yang tidak wajar. Hal berdampak bahwa seolaholah KUHP hanya memberikan perlindungan khusus terhadap bendera dan lambang negara Republik Indonesia bahkan lambang negara lain dari tindak pidana penghinaan sedangkan Presiden atau Wakil Presiden Indonesia tidak memperoleh perlindu- 
ngan khusus seperti bendera dan lambang negara Republik Indonesia serta lambang negara lain. Jika disandingkan secara sejajar, seharusnya Presiden dan Wakil Presiden bersama dengan bendera dan lambang negara Republik Indonesia merupakan simbol kenegaraan yang tidak bisa saling dipisahkan. Pada saat bendera dan lambang negara Republik Indonesia masih diberi pengaturan secara khusus, maka sudah sepantasnya presiden dan wakil presiden juga diberi perlindungan dan pengaturan secara khusus, sehingga tercipta keseimbangan diantara ketiganya

\section{PENUTUP}

Terhadap legal reasoning putusan MK, penulis tidak sependapat, karena:

1. Ketika ada hak kebebasan berpendapat, termasuk di dalamnya kebebasan untuk mengkritik presiden atau wakil presiden, maka disitu juga akan muncul batasan terhadap hak kebebasan berpendapat sebagaimana Pasal 28J ayat (1) dan (2) UUD 1945.

2. Perlu dilihat kedudukan Presiden sebagai kepala negara sekaligus simbol negara, dimana perlu adanya perlindungan khusus. Martabat presiden selalu melekat pada jabatannya yang tidak dapat saling dipisahkan. Terutama adalah perbuatan menghina merupakan tindak pidana dan secara teoritik dapat dikatakan sebagai mala per se.

3. Putusan MK juga memberikan dampak juridis yakni merusak sistem gradasi nilai di dalam KUHP itu sendiri. Pembatalan pasal penghinaan terhadap presiden ini membuat segala bentuk penghinaan terhadap presiden dianggap bukan sebagai tindak pidana. Tidak ada lagi perlindungan terhadap martabat presiden terkait dengan jabatan yang dimilikinya. Sedangkan di sisi lain, penghinaan terhadap masyarakat biasa merupakan delik. Begitu juga penghinaan terhadap raja, kepala negara lain atau perwakilan negara lain juga masih diakomodasi di dalam KUHP. Bahkan penodaan terhadap bendera dan lambang negara Indonesia serta penghinaan bendera negara asing juga masih berlaku dalam KUHP.

\section{DAFTAR BACAAN}

\section{Buku}

Anwar Y, dan Adang, Pembaharuan Hukum Pidana - Reformasi Hukum Pidana (Gramedia Widiasarana Indonesia 2008).

Pujiyono, Kumpulan Tulisan Hukum Pidana - Kriminalisasi Atas Kebebasan Pers dalam Perspektif Hukum Pidana (CV Mandar Maju 2007).

Wahidin S, Hukum Pers (Pustaka Pelajar 2006).

\section{Artikel Jurnal}

Arzagi N, 'Kebijakan Hukum Pidana Dalam Upaya Menanggulangi LGBT Berbasis Nilai-Nilai Pancasila' (2018) 2 (2) Refleksi Hukum: Jurnal Ilmu Hukum.

Purnamasari Galuh C, 'Kewenangan Mahkamah Konstitusi dalam Melakukan Judicial Review terhadap Undang-Undang Ratifikasi Perjanjian Internasional' 
(2017) 2 (1) Refleksi Hukum: Jurnal Ilmu Hukum.

Widayati Lidya S, 'Tindak Pidana Penghinaan Terhadap Presiden dan Wakil Presiden: Perlukah Diatur Kembali dalam KUHP?' (2017) 8 (2) Negara Hukum.

\section{Makalah Seminar/Konferensi}

Zein Patra M, 'Kebebasan Menyampaikan Pendapat: Perspektif Hukum Hak Asasi Manusia' (Pertemuan Ahli 'Tinjauan tentang Tindak Pidana terhadap Kebebasan Menyampaikan Pendapat dalam RUU KUHP' diselenggarakan Komisi Hukum Nasional, Jakarta, Oktober 2008).

\section{Putusan Pengadilan}

Putusan Mahkamah Konstitusi Republik Indonesia Nomor 013022/PUU-IV/2006, Mahkamah Konstitusi, 4 Desember 2006.

\section{Peraturan Perundang-Undangan}

Undang-Undang Dasar Negara Republik Indonesia Tahun 1945.

Kitab Undang-Undang Hukum Pidana.

Undang-Undang Nomor 12 Tahun 2005 tentang Pengesahan International Covenant On Civil and Political Rights (Kovenan Internasional Tentang Hak-Hak Sipil dan Politik).

\section{Lainnya}

Asshiddiqie J, Konstitusi dan Hak Asasi Manusia, Bahan Disampaikan Pada Lecture Peringatan 10 Tahun Kontras, Jakarta, 26 Maret 2008.

Naskah Rancangan Kitab UndangUndang Hukum Pidana (RKUHP) Hasil Pembahasan Panitia Kerja R-
KUHP DPR RI Hingga Tanggal 24 Februari 2017. 